【論文】

UDC : $691.32: 666.97: 620.191 .3$

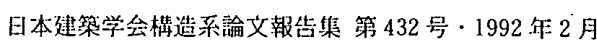
Journal of Struct. Constr. Engng, AIJ, No. 432, Feb., 1992

\title{
コンクリート切り欠き試験体の曲げ試験による ひびわれ補修材料の評価 \\ EVALUATION OF CRACK REPAIR MATERIALS BY MEANS OF BENDING TEST ON NOTCHED CONCRETE SPECIMEN
}

\author{
橘高 義 典*, 上村 克 郎**, 中村成 春*** \\ Yoshinori KITSUTAKA, Katsurou KAMIMURA and Shigeharu NAKAMURA
}

\begin{abstract}
Restoration of strength properties of crack repaired concrete specimen has been studied. Threepoint bend tests were carried out on undamaged notched concrete specimens and damaged ones which crack repaired by epoxy resin, and restoration of the specimen was evaluated by means of fracture mechanics parameters such as the fracture energy $G_{F}$ and the bending strength. The bending strength of repaired concrete specimen was proportional to the E-modulus of resin, and inversely proportional to the width of crack. The fracture energy $\left(G_{F}\right)$ of repaired concrete specimens decreased with increasing the E-modulus of resin. The $G_{F}$ value of repaired concrete were did not monotonously increase with increasing compressive strength of concrete, and had a tendency of decrease at low water cement ratio.
\end{abstract}

Keywords : crack, repair, fracture energy, high-strength concrete ひびわれ，補修，破壊エネルギー，高強度コンクリート

\section{1.はじめに}

コンクリート構造物のひびわれは，構造物の安全性, 耐久性，耐水性等を損なう原因であり，その適切な補修 方法の確立は重要な研究課題である。特に荷重作用等に よって構造部材に発生したひびわれの補修は構造物の機 能回復や安全性回復の点で重要であり，それらをどのよ うな材料・工法で補修し強度回復を図るかは今日的な課 題となっている。

近年, ひびわれの補修方法としてエポキシ樹脂あるい はポリマーセメントスラリー等の接着材料を用いた注入 工法が注目されている"。これは，ひびわれ空隙内に適 度な粘性を持つ接着材を加圧注入し硬化させることによ り，ひびわれ空隙を硬化材で充填し，漏水の防止ならび に部材強度の回復を図るものである。注入工法によるひ びわれ補修の利点としては，適度な接着力および強度を 有する接着材料でひびわれ面を固着することによりひび われ発生以前のコンクリート部材と同等の強度回復が期 待できる点が挙げられるが2!，さらに伸び能力を有する 接着材料を使用することにより, 接着材料の変形能が勒 性の向上に寄与し，元来コンクリートが持つ脆性的な性
質の改善も期待できるものと考えられる。特にエポキシ 樹脂による梁部材の注入補修では他の補修方法よりも剛 性ならびに䩛性回復が優れるとの報告もある3!。

また最近では, 高強度コンクリートの建築構造物への 適用・研究が盛んであるが, 従来の普通強度のコンク リートに加えて高強度域のコンクリートの補修の必要性 も考慮すると，広範囲なコンクリート強度での補修材料 の補修効果を明らかにする必要がある。特に強度の増大 に伴い，コンクリートの破壊は脆性的な傾向を示すこと が指摘されており ${ }^{4) .51}$, その補修については強度回復の みならず勒性の向上も付与できることが望ましい。

以上の諸点を明らかにするためには，さまざまな強度 およびひびわれ幅を有するコンクリートの補修後の強度 性に及ぼす補修材料の性質を材料レベルで明確にする必 要があるが，これらに関する研究例は少ない。ひびわれ 内部への樹脂の充填性に関しては筆者らが樹脂の性質, ひびわれ幅，注入圧等に関し定式的な関係を明らかにし ている6)。今泉・国原らは接着された部材の力学的性状

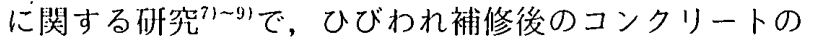
純引㖘強度および割裂強度に及ぼす接着剤の性質の影響

\footnotetext{
* 宇都宮大学工学部建設学科 助手・工博

** 宇都宮大学工学部建設学科 教授・正博

*** 宇都宮大学 大学院生
}

Research Assoc., Dept. of Architecture and Civil Engineering, Facul ty of Engineering, Utsunomiya Univ., Dr. Eng.

Prof., Dept. of Architecture and Civil Engineering, Faculty of En. gineering, Utsunomiya Univ., Dr. Eng. Graduate Student, Utsunomiya Univ. 
を検討している。H.D. Kleinschrodt ${ }^{10)}$ は, 硬化樹脂に より補修したコンクリートの破壊エネルギーを求めた結 果, 補修前よりも破壊エネルギーはやや向上する傾向に あるとの報告を行っている。しかしながら，広範囲の強 度域およびひびわれ幅を有するコンクリートの補修後の 強度性状および勒性に及ぼす硬化樹脂の性質に関して検 討を行った例は見られない。

本研究は，エポキシ樹脂によりひびわれ補修したコン クリートの強度回復性を, 切り欠きを有するコンクリー 卜直方試験体の曲げ試験により評価することとし, 補修 前後の試験体の曲げ強度ならびに破壊エネルギーに及ぼ すコンクリート強度, ひびわれ幅, エポキシ樹脂の引張 弾性係数等の影響を明らかにすることを目的とする。

\section{2. ひびわれ補修材料の評価方法}

ひびわれ補修後の強度性状の評価方法には, モルタル 試験体の曲げ試験によるもの"1)，コンクリート円柱供試 体の割裂試験を用いたもの ${ }^{8), 9)}$, 純引張試験としたもの ${ }^{7)}$,

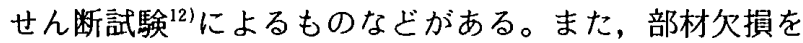
有するコンクリート試験体の補修性能を曲げ試験により 評価している例 ${ }^{13)} も$ ある。しかしながら, 強度評価と同 時に勒性評価を行うためには, 安定した荷重一変位曲線 から, 破壊時までの吸収エネルギーを精度よく求める必 要がある。そこで本研究では, 近年そのコンクリート工 学への適用が検討されている破壊力学的手法に着目し, モードIの破壊勒性試験により補修前後のコンクリート 試験体の評価を行うこととした。すなわち，中央に切り 欠きを有するコンクリート試験体の 3 点曲げ試験を，健 全試験体および曲げ破壊後りガメント部（ひびわれ破壊 部分）を補修した試験体について行い, 荷重一変位曲線 を求め最大曲げ強度および破壊䳬性值を求めた。破壊䳬 性値は, 荷重-変位曲線で囲まれた面積を破壊面の投影 断面積で除した破壊エネルギー $G_{F}{ }^{141}$ とした。

なお，本評価方法では，ひびわれ補修を行う試験体に は荷重履歴により微細ひびわれの蓄積したいわゆるフラ クチャープロセスゾーンが形成されており，健全なコン クリートを樹脂で接着した場合での評価值とは異なる。 また，補修後の試験体にも切り欠き部から強制的にひび われを発生されるものである。したがって，本試験方法 は，補修材料の強度回復性状を相対的に評価する一試験 方法と位置づけられる。

切り欠き試験体での曲げ強度 $f_{b}\left(\mathrm{kgf} / \mathrm{cm}^{2}\right)$ は下式に より求めた101。

$$
f_{0}=\frac{1.5 l \cdot\left(F_{\max }+m g / 2\right)}{a \cdot b^{2}} .
$$

ここに,

$$
l: \text { スパン }(\mathrm{cm})
$$

$F_{\text {max }}$ : 最大荷重 $(\mathrm{kgf})$

$-2-$ $m g ：$ 試験体自重 $(\mathrm{kgf})$

$$
\begin{aligned}
& a: \text { リガメント幅 }(\mathrm{cm}) \\
& b: \text { リガメント高さ }(\mathrm{cm})
\end{aligned}
$$

また, 破壊エネルギー $G_{F}(\mathrm{kgf} / \mathrm{cm})$ は RILEM が提 唱する下式 ${ }^{(4)}$ で求めた。

$$
G_{F}=\frac{W_{0}+m g \cdot \delta_{0}}{A_{11 g}}
$$

ここに

$W_{0}:$ 荷重-変位曲線下の面積 $(\mathrm{kgf} \cdot \mathrm{cm})$

$m g:$ 試験体の自重 $(\mathrm{kgf})$

$\delta_{0}:$ 破断時の垂直変位 $(\mathrm{cm})$

$A_{118}$ : リガメントの垂直投影喕積 $\left(\mathrm{cm}^{2}\right)$

\section{3. 実験概要}

3.1 コンクリートの種類

コンクリートの強度は, 通常使用される強度に加え高 強度域を考慮し, 水セメント比を $25,35,50,65 \%$ の 4 条件とした。水セメント比 $25 \%$ および $35 \%$ の条件 では高性能娍水㓮（アニオン型特殊活性剤, WH 2000) を使用した。また，粗骨材の絶対容積はいずれの水セメ ント比でも $4001 / \mathrm{m}^{3}$ 一定とした。使用した骨材の性質

\begin{tabular}{|c|c|c|c|c|c|c|c|c|c|}
\hline \multicolumn{2}{|c|}{ 月材の相数 } & 䖝地 & 极大 & 走故比面 & 彼水平 & & 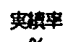 & 相望 & \\
\hline 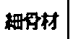 & III 础 & 兵 & 5 & & & & - & & 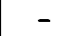 \\
\hline $3+$ & 制 & II & 20 & 60 & 41 & 89 & .4 & 67 & \\
\hline
\end{tabular}
を表一1に，コンクリートの調合条件を表一 2 に示す。 また，フレッシュコンクリートの性質ならびに材令 9 週

\begin{tabular}{|c|c|c|c|c|c|c|c|c|}
\hline \multirow[t]{2}{*}{ 壾 可 } & \multirow{2}{*}{$\begin{array}{c}\text { 水她冰 } \\
W / C \\
x\end{array}$} & \multirow{2}{*}{$\begin{array}{c}\text { 䉽㖊材率 } \\
\mathbf{s} / \mathbf{a} \\
\%\end{array}$} & \multirow{2}{*}{ 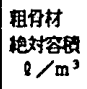 } & \multirow{2}{*}{ 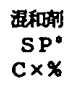 } & \multicolumn{2}{|c|}{ 些证 } & \multicolumn{2}{|c|}{$\mathrm{kg} / \mathrm{m}^{3}$} \\
\hline & & & & & 水 & セメシト & 梱材材 & 蛙角材 \\
\hline C25 & 25 & 42.7 & 400 & 3.6 & 129 & 516 & 780 & 1040 \\
\hline C 35 & 35 & 42.7 & 400 & 1.0 & 153 & 438 & 790 & 1040 \\
\hline C5O & 50 & 42.7 & 400 & - & 179 & 358 & 790 & 1040 \\
\hline C6 5 & 65 & $42 \cdot 7$ & 400 & - & 197 & 303 & 790 & 1040 \\
\hline
\end{tabular}
（補修試験体試験材令）での強度性状を表一 3 に示す。

\section{表一1＼cjkstart骨材の性質}

\begin{tabular}{|c|c|c|c|c|c|c|c|}
\hline 眍 号 & $\begin{array}{c}\text { 緅上湿度 } \\
\mathrm{T} \\
\mathrm{C}\end{array}$ & $\begin{array}{l}\text { スランフ } \\
\text { SL } \\
\mathrm{cm}\end{array}$ & $\begin{array}{c}\text { スランフ } \\
\text { フロー值 } \\
\mathrm{mm}\end{array}$ & $\begin{array}{c}\text { 空 気 } \\
\text { (任力法) } \\
\text { \% }\end{array}$ & $\begin{array}{c}\text { 因的的度 } \\
f \mathrm{c} \\
\mathrm{kgf} / \mathrm{cm}^{2}\end{array}$ & $\begin{array}{c}\mathrm{ft} \\
\mathrm{kgf} / \mathrm{cm}^{2}\end{array}$ & 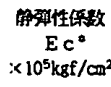 \\
\hline C 25 & 29.5 & 24.0 & $475 \times 450$ & 2.4 & 738 & 40.0 & 4.01 \\
\hline c35 & 28.0 & 17.5 & $325 \times 310$ & 2.4 & 592 & 33.2 & 4.22 \\
\hline C5o & 26.5 & 16.0 & $245 \times 240$ & 1.5 & 489 & 34.9 & 3. 13 \\
\hline C65 & 22.0 & 20.5 & $400 \times 430$ & 0.6 & 292 & 31.0 & 2.51 \\
\hline
\end{tabular}

表一2 コンクリートの調合条件

表一3 フレッシュコンクリートの性質および材令 9 週での強度 性状 
表一4 エポキシ樹脂の調合

\begin{tabular}{|c|c|c|c|c|c|c|}
\hline & & 每 & R 1 & $\mathbf{R} 2$ & R3 & R4 \\
\hline 主 & 䎴 & 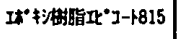 & 100 & 100 & 100 & 100 \\
\hline & .1 & 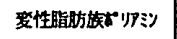 & 60 & 20 & - & - \\
\hline 㹬化 & .2 & 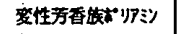 & 20 & 40 & 80 & 60 \\
\hline F & 㹸 & 活础 & - & - & - & 640 \\
\hline
\end{tabular}

表一5 エポキシ樹脂の性質

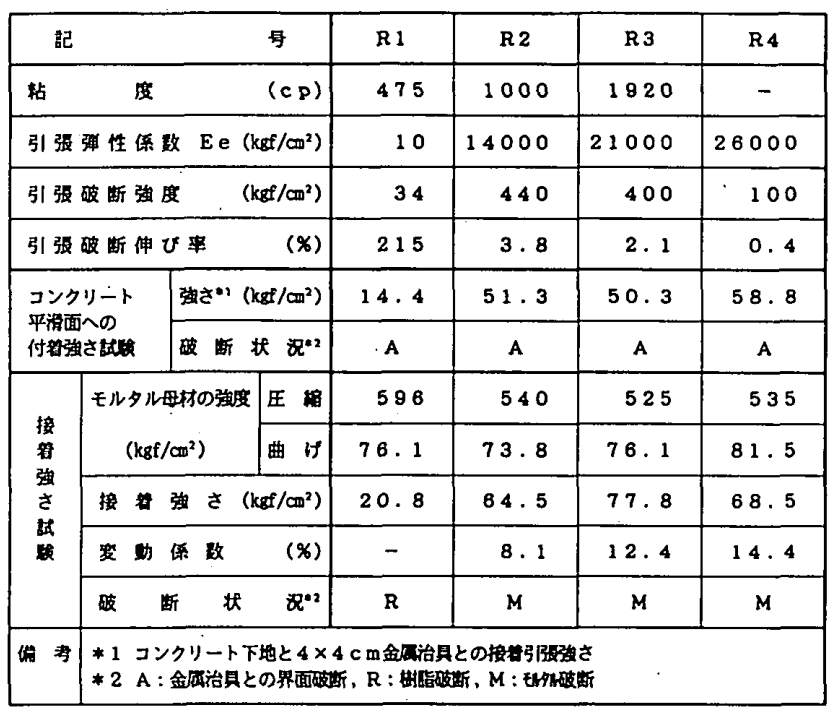

\section{2 エポキシ樹脂の種類}

今回は補修材料の特性として引張弾性係数に着目し, 補修材料には硬化材の調合条件により引張弾性係数を制 御できるエポキシ樹脂を使用することとした。使用した 樹脂は主剤がエピコート 815, 硬化刘 No. 1 が変性脂肪 族ポリアミン，硬化郕 No. 2 が変性芳香族ポリアミンで あり，硬化剤 No.1 と No. 2 の混合比率を変えることに より引張弾性係数を変化させた。すなわち実施工で用い られているエポキシ樹脂の弾性係数よりも広範囲の条件 を設定することとし，計 4 種類の調合条件を設定した。 なお,最も引張弾性係数の大きい条件では骨材を混入し， それにはセメントの物理試験用に用いられている豊浦産 標準砂を使用した。樹脂の重量調合比を表一4に示す。

\section{3 エポキシ樹脂の性質}

表一 5 中にはエポキシ樹脂の各種性質を示した。樹脂 の引張弾性係数, 引張破断時強度, 引張破断時伸び等は JIS K 6911 に従った。試験体はひびわれ補修に用いた ものと同様の条件で作製，養生 $\left(20^{\circ} \mathrm{C}, 60 \% \mathrm{RH}\right)$ し， 試験材令も補修後の曲げ試験之同一とした。コンクリー 卜平滑面への付着強さは，樹脂のコンクリート面への接 着強さの参考値として求奻た。 $40 \times 40 \mathrm{~mm}$ の付着面積 をもつ金属治具をグラインダー処理したコンクリート面 に樹脂で接着し，1 週間後に引張試験を行い最大荷重を 接着面積で除し付着強さとした。使用したコンクリート
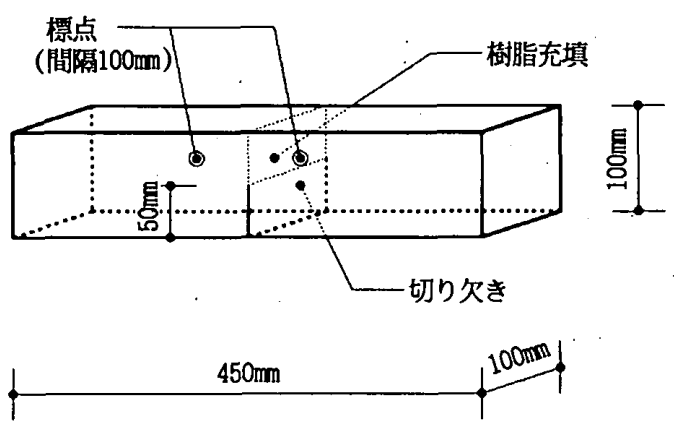

図一1 試験体の概要

強度は $400 \sim 600 \mathrm{~kg} / \mathrm{cm}^{2}$ の範囲であった。接着強さは JIS A 6024「建築補修用注入エポキシ樹脂」に準じて求 めた。すなわち，JIS R 5201 により作製した $40 \times 40 \times$ $160 \mathrm{~mm}$ のモルタル試験体の曲げ試験を行い，その後 40 $\times 40 \mathrm{~mm}$ の型枠脱型面 2 面を $1 \mathrm{~mm}$ の鋼線を介し挟み, その間に樹脂を注入し接着させ， 1 週間養生後曲げ試験 を行い, 曲げ強度を求め接着強さとした。

\section{4 試験体概要}

3 点曲げ試験に用いるコンクリート試験体の寸法は $100 \times 100 \times 450 \mathrm{~mm}$ で，リガメント長さは試験体せいの $1 / 2$ の $50 \mathrm{~mm}$ とし, 試験体数は各条件について 3 体と した。試験体の概要を図一1に示す。試験体は鋼製型枠 に打設後 2 日で脱型，以後 $20^{\circ} \mathrm{C}$ で水中養生とした。材 令 8 週目に切り欠き試験体の曲げ試験を行った。試験体 の切り欠きは試験直前にコンクリートカッターで作製し た。曲げ試験後の破断試験体は $20^{\circ} \mathrm{C}, 60 \% \mathrm{RH}$ の恒温 恒湿室で 24 時間乾燥後, 破断面をエポキシ樹脂により 接着補修した。

\section{5 補修方法の概要}

エポキシ樹脂による接着補修の手順は以下のとおりで ある。曲げ試験により破断した試験体の切り欠き間に木 製スペーサーを挟み継ぎ合わせ，リガメント間に所定の 隙間幅を作る。試験体はリガメント部が下面になるよう 横に置き，ひびわれ部をはく離性ウレタン系シール材で 上面以外を除き 3 面シールする。3 時間後シール材が硬 化してから，スペーサーを外し，エポキシ樹脂を注射器 を用いひびわれ間にひびわれ上部から注入する。5，6 時間後にさらに予備注入を行い隙間を完全に樹脂で充填 する。その後再度スペーサーを切り欠き部に挟み 3 日間 養生し,シール材を剝し曲げ試験まで約 4 日間養生する。 なお，粘度が最も大きい樹脂 R 4 ではひびわれへの注 入が不可能であったため,ひびれ面へ樹脂を直接塗布し， 所定のひびわれ幅が得られるように切り欠き部にスペー サーを挟みひびわれ面を接着させることとした。

ひびわれ条件は，0.5，1.5，3.0 mm の3 段階とした。 あらかじめ曲げ試験による破断前ならびに樹脂補修後に 試験体側面に貼った標点間の距離をコンタクトゲージに より測定し，その差からひびわれ幅を求めることとし， 


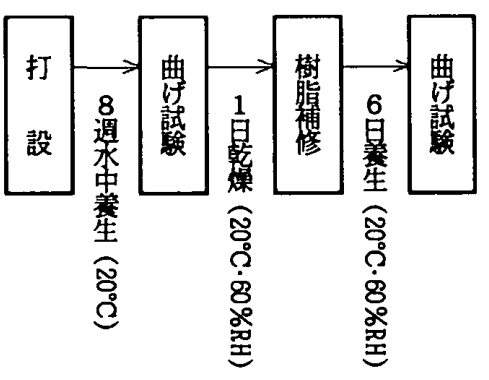

図一2 実験手順

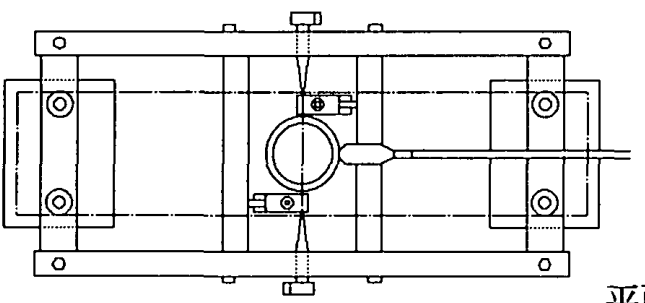

平面図

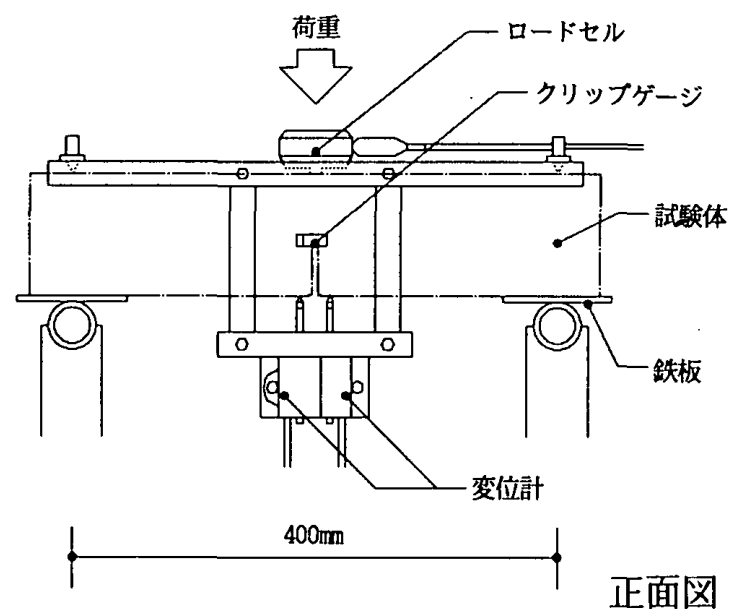

図一3 曲げ試験概要

所定のひびわれ幅が得られるようスペーサーの厚さを調 節した。

補修後の試験体の曲げ試験は材令 8 週の曲げ試験から 1 週間後の 9 週目に行った。

以上の実験手順を図一 2 にまとめて示す。

3.6 曲げ試験の概要

曲げ試験は以下の要領で行った。油王サーボ型載荷試 験機に試験体を図一 3 のように取り付け，試験体中央に 一定速度（10～12 kg/sec）で載荷した。垂直荷重は $500 \mathrm{~g}$ 感度のロードセルにて検出し, 裁荷点下部の垂直 変位は治具に取付けた $0.005 \mathrm{~mm}$ 感度の変位計により 2 点測定し，いずれもデータアナライザに入力し $0.1 \mathrm{sec}$ の間隔で記録した。変位計の取付冶具は支点部のめり込 みの影響を除去するとの意図による。XYレコーダーに 荷重-変位曲線を同時に記録した。荷重-变位曲線の安定 性を確認するために，リガメント端部（試験体中央）の 開口変位も参考値としてクリップゲージにて計测した。 ひびわれ破断時の垂直変位. $\delta_{0}$ は, データアナライザに
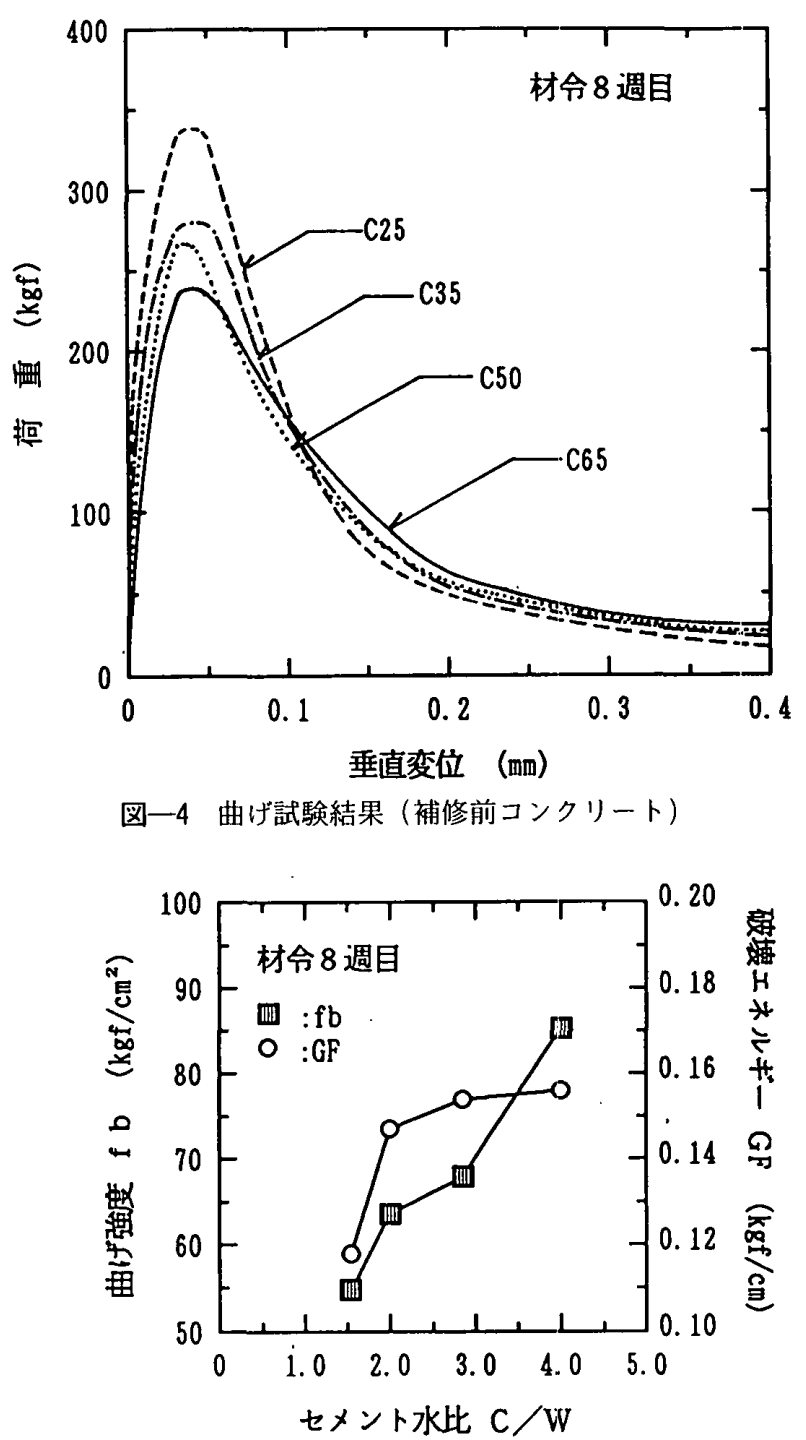

图一-5 セメント水比と強度性状（補修前コンクリート）

記録したデータを分析し変位が急激に増加し始めた点と した。

\section{4. 実験結果および考察}

\section{1 補修前の試験体に関する結果および考察}

図一 4 に材令 8 週での健全試験体の荷重-変位測定結 果例を示す。荷重一変位曲線は破断時まで安定した曲線 となっている。本図より低水セメント比の試験体ほど最 大耐力ならびに初期の剛性は増加するが，最大荷重後の 荷重-変位曲線の落ち込みの程度が大きくなる傾向にあ り，曲線で曲まれる面積は必ずしも増大していない。

図一5に材令 8 週目での曲げ強度および破填エネル ギー測定值とセメント水比との関係を示す。試駼体総数 は 36 本でありその平均値で示した。曲げ強度はセメン 卜水比が大きくなるほど増大する傾向にあるが，破壊工 ネルギーはセメント水比に単純に比例せず高セメンント水 比で頭打ちの傾向がある。すなわちペーストマトリック スの強度が増大するほどコンクリートの強度は大きくな 
表一6 曲げ強度測定結果

\begin{tabular}{|c|c|c|c|c|c|c|c|c|c|}
\hline \multicolumn{2}{|c|}{ 明脂の租数 } & \multirow{2}{*}{\multicolumn{2}{|c|}{$\frac{R 1}{10}$}} & \multirow{2}{*}{\multicolumn{2}{|c|}{$\frac{\text { R2 }}{14000}$}} & \multirow{2}{*}{\multicolumn{2}{|c|}{$\frac{R 3}{21000}$}} & \multirow{2}{*}{\multicolumn{2}{|c|}{$\frac{R 4}{26000}$}} \\
\hline Ee & $\mathrm{cgf}_{\mathrm{g}} / \mathrm{cm}^{2}$ & & & & & & & & \\
\hline $\begin{array}{c}\text { Wobte } h \\
\mathrm{~mm}\end{array}$ & 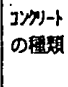 & $\begin{array}{c}f b \\
\text { 平均值 } \\
\mathrm{kgf} / \mathrm{cm}^{2}\end{array}$ & 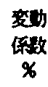 & $\begin{array}{c}\mathrm{fb} \\
\text { 平㘬值 } \\
\mathrm{kgf} / \mathrm{cm}^{2}\end{array}$ & $\begin{array}{l}\text { 倡数 } \\
\text { \% }\end{array}$ & $\begin{array}{c}f b \\
\text { 平㘬值 } \\
\mathrm{kgf} / \mathrm{cm}^{2}\end{array}$ & $\begin{array}{l}\text { 效数 } \\
\text { 数 } \\
x\end{array}$ & $\begin{array}{l}\mathrm{f} \mathrm{b} \\
\text { 平部值 } \\
\mathrm{kgf} / \mathrm{cm}^{2}\end{array}$ & $\begin{array}{l}\text { 变地 } \\
\text { 数 } \\
x\end{array}$ \\
\hline 0.5 & $\mid \begin{array}{lll}C & 25 \\
C & 3 & 5 \\
C & 5 & 0 \\
C & 8 & 5\end{array}$ & $\begin{array}{l}17.3 \\
34.9 \\
45.1 \\
25.6\end{array}$ & $\begin{array}{r}33.1 \\
22.6 \\
4.8 \\
28.1\end{array}$ & $\begin{array}{c}- \\
69.2 \\
44.4 \\
47.7\end{array}$ & $\begin{array}{c}- \\
11.9 \\
25.4 \\
10.4\end{array}$ & $\begin{array}{l}54.7 \\
\oplus .1 \\
32.1 \\
51.2\end{array}$ & $\begin{array}{r}3.7 \\
8.4 \\
17.7 \\
-\end{array}$ & $\begin{array}{c}63.7 \\
70.0 \\
46.0 \\
-\end{array}$ & $\begin{array}{c}- \\
\overline{11.9} \\
-\end{array}$ \\
\hline 1. . 5 & $\mid \begin{array}{l}C 25 \\
C \quad 35 \\
C 550 \\
C 665\end{array}$ & $\begin{array}{c}17.3 \\
22.4 \\
33.1 \\
-\end{array}$ & $\begin{array}{c}13.8 \\
17.8 \\
3.3 \\
-\end{array}$ & $\begin{array}{c}60.5 \\
73.7 \\
63.3 \\
-\end{array}$ & $\begin{array}{r}20.4 \\
22.2 \\
8.8 \\
-\end{array}$ & $\begin{array}{l}73.9 \\
73.7 \\
73.0 \\
39.1\end{array}$ & $\begin{array}{c}14.9 \\
10.6 \\
13.4 \\
-\end{array}$ & $\begin{array}{l}79.8 \\
72.0 \\
66.9 \\
44.6\end{array}$ & $\begin{array}{r}8.0 \\
9.8 \\
10.8 \\
7.8\end{array}$ \\
\hline 3.0 & $\begin{array}{lll}C & 2 & 5 \\
C & 3 & 5 \\
C & 5 & 0 \\
C & 6 & 5\end{array}$ & $\begin{array}{r}9.2 \\
11.9 \\
22.3 \\
15.0\end{array}$ & $\begin{array}{r}20.2 \\
7.5 \\
12.1 \\
-\end{array}$ & $\begin{array}{l}40.1 \\
55.0 \\
47.2 \\
34.3\end{array}$ & $\begin{array}{r}16.4 \\
2.9 \\
9.9 \\
-\end{array}$ & $\begin{array}{l}74.0 \\
63.4 \\
60.6 \\
55.4\end{array}$ & $\begin{array}{l}5.1 \\
8.4 \\
3.2 \\
-\end{array}$ & $\begin{array}{l}78.0 \\
71.6 \\
84.2 \\
56.6\end{array}$ & $\begin{array}{r}8.8 \\
11.5 \\
7.6 \\
12.7\end{array}$ \\
\hline
\end{tabular}

表一7 破壊エネルギー測定結果

\begin{tabular}{|c|c|c|c|c|c|c|c|c|c|}
\hline \multicolumn{2}{|c|}{ 时踏の種類 } & \multirow{2}{*}{\multicolumn{2}{|c|}{$\frac{R 1}{10}$}} & \multirow{2}{*}{\multicolumn{2}{|c|}{$\frac{R 2}{14000}$}} & \multirow{2}{*}{\multicolumn{2}{|c|}{$\frac{\text { R3 }}{21000}$}} & \multirow{2}{*}{\multicolumn{2}{|c|}{$\frac{\text { R4 }}{26000}$}} \\
\hline E e & $\mathrm{kgf} / \mathrm{cm}^{2}$ & & & & & & & & \\
\hline $\begin{array}{c}\text { Wothht } \mathrm{h} \\
\mathrm{mm}\end{array}$ & 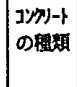 & $\begin{array}{l}\mathrm{GF} \\
\text { F均值 } \\
\mathrm{kgf} / \mathrm{cm}\end{array}$ & 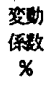 & $\begin{array}{c}\text { GF } \\
\text { 平均值 } \\
\mathrm{kgf} / \mathrm{cm}\end{array}$ & 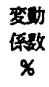 & $\begin{array}{c}\mathrm{GP} \\
\text { 平均值 } \\
\mathrm{kgt} / \mathrm{cm}\end{array}$ & $\begin{array}{c}\text { 煙 } \\
\text { 致 } \\
\%\end{array}$ & $\begin{array}{c}\mathrm{GF} \\
\text { 平均值 } \\
\mathrm{kgf} / \mathrm{cm}\end{array}$ & 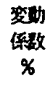 \\
\hline 0.5 & $\begin{array}{l}\text { C } 25 \\
\text { C } 35 \\
\text { C5 } 50 \\
\text { C } 655\end{array}$ & $\begin{array}{l}0.274 \\
0.629 \\
0.752 \\
0.518\end{array}$ & $\begin{array}{r}8.4 \\
8.1 \\
8.0 \\
33.5\end{array}$ & $\begin{array}{c}- \\
0.501 \\
0.381 \\
0.282\end{array}$ & $\begin{array}{l}- \\
8.8 \\
3.4 \\
8.2\end{array}$ & $\begin{array}{l}0.201 \\
0.280 \\
0.175 \\
0.142\end{array}$ & $\begin{array}{c}18.4 \\
14.2 \\
19.6 \\
-\end{array}$ & $\begin{array}{c}0.206 \\
0.250 \\
0.171 \\
-\end{array}$ & $\begin{array}{c}- \\
- \\
12.3 \\
-\end{array}$ \\
\hline 1.5 & 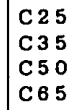 & $\begin{array}{c}0.467 \\
0.619 \\
1.010 \\
-\end{array}$ & $\begin{array}{r}14.3 \\
8.6 \\
8.7 \\
-\end{array}$ & $\begin{array}{c}0.324 \\
0.344 \\
0.458 \\
-\end{array}$ & $\begin{array}{r}5.3 \\
8.1 \\
28.8 \\
-\quad\end{array}$ & $\begin{array}{l}0.253 \\
0.207 \\
0.318 \\
0.178\end{array}$ & $\begin{array}{r}24.6 \\
7.3 \\
22.5 \\
-\end{array}$ & $\begin{array}{l}0.289 \\
0.245 \\
0.151 \\
0.183\end{array}$ & $\begin{array}{r}7.9 \\
8.7 \\
20.5 \\
40.6\end{array}$ \\
\hline 3. 0 & $\begin{array}{l}\text { C } 25 \\
\text { C } 35 \\
\text { C } 550 \\
\text { C } 65\end{array}$ & $\begin{array}{l}0.294 \\
0.733 \\
0.664 \\
0.522\end{array}$ & $\begin{array}{r}18.2 \\
4.8 \\
13.0 \\
-\end{array}$ & $\begin{array}{l}0.313 \\
0.488 \\
0.276 \\
0.432\end{array}$ & $\begin{array}{r}9.6 \\
9.7 \\
24.6 \\
-\end{array}$ & $\begin{array}{l}0.211 \\
0.347 \\
0.137 \\
0.186\end{array}$ & $\begin{array}{c}40.0 \\
21.6 \\
13.8 \\
-\end{array}$ & $\begin{array}{l}0.301 \\
0.251 \\
0.147 \\
0.267\end{array}$ & $\begin{array}{l}22.5 \\
22.5 \\
25.1 \\
15.1\end{array}$ \\
\hline
\end{tabular}

表一8 曲げ試験での破壊状洗

\begin{tabular}{|c|c|c|c|c|c|c|c|c|c|c|c|c|c|}
\hline \multicolumn{2}{|c|}{ 猎の租類 } & \multicolumn{3}{|c|}{ R 1} & \multirow{2}{*}{\multicolumn{3}{|c|}{$\frac{R 2}{14000}$}} & \multirow{2}{*}{\multicolumn{3}{|c|}{$\frac{\text { R3 }}{21000}$}} & \multirow{2}{*}{\multicolumn{3}{|c|}{$\frac{R 4}{26000}$}} \\
\hline \multicolumn{2}{|c|}{ Ee $\quad \mathrm{kgf} / \mathrm{cm}^{2}$} & \multicolumn{3}{|c|}{10} & & & & & & & & & \\
\hline $\begin{array}{c}\text { Westht憎 } \mathrm{h} \\
\mathrm{mm}\end{array}$ & 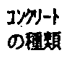 & 1 & 2 & 3 & 1 & 2 & 3 & 1 & 2 & 3 & 1 & 2 & 3 \\
\hline 0.5 & $\begin{array}{l}\text { C } 25 \\
\text { C } 35 \\
\text { C } 550 \\
\text { C } 85\end{array}$ & $\begin{array}{l}\text { I } \\
\text { I } \\
\text { I } \\
\text { I }\end{array}$ & $\begin{array}{l}I \\
I \\
I \\
I\end{array}$ & $\begin{array}{l}\text { I } \\
\text { I } \\
\text { I }\end{array}$ & $\begin{array}{l}- \\
\text { CI } \\
C \\
C\end{array}$ & $\begin{array}{l}- \\
c \\
c \\
c\end{array}$ & $\begin{array}{l}- \\
\text { CI } \\
\text { CI } \\
\text { CI }\end{array}$ & $\begin{array}{c}\mathrm{C} I \\
\mathrm{C} \\
\mathrm{CI} \\
-\end{array}$ & $\begin{array}{l}- \\
\mathbf{C} \\
\mathrm{C} \\
\mathrm{C}\end{array}$ & $\begin{array}{l}C_{\text {I I }} \\
\text { C } \\
\text { C } \\
-\end{array}$ & $\begin{array}{l}\bar{c} \\
- \\
-\end{array}$ & $\begin{array}{l}- \\
\mathrm{C} \\
\mathrm{C} \\
-\end{array}$ & $\begin{array}{l}c \\
- \\
c \\
-\end{array}$ \\
\hline 1.5 & $\begin{array}{l}C 25 \\
C \quad 35 \\
C 55 \\
C 65\end{array}$ & $\begin{array}{l}I \\
I \\
I \\
-\end{array}$ & $\begin{array}{l}I \\
I \\
I \\
-\end{array}$ & $\begin{array}{l}\text { I } \\
\text { I } \\
\text { I }\end{array}$ & $\begin{array}{c}\mathrm{CI} \\
\mathrm{C} \\
\mathrm{C} \\
-\end{array}$ & $\begin{array}{c}\text { C I } \\
C \\
C \\
-\end{array}$ & $\begin{array}{l}\text { C I } \\
\text { C I } \\
\text { C } \\
-\end{array}$ & $\begin{array}{c}C I \\
C \\
C \\
-\end{array}$ & $\begin{array}{c}C I \\
C \\
C \\
C I\end{array}$ & $\begin{array}{l}\text { CI } \\
\text { C } \\
\text { C } \\
-\end{array}$ & $\begin{array}{l}\text { C } \\
\text { C } \\
\text { C } \\
\text { C }\end{array}$ & $\begin{array}{l}\mathrm{C} \\
\mathrm{C} \\
\mathrm{C} \\
\mathrm{C}\end{array}$ & $\begin{array}{c}\mathrm{C} \\
\mathrm{C} \\
\mathrm{C} \\
\mathrm{C} I\end{array}$ \\
\hline 3.0 & 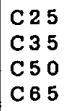 & $\begin{array}{l}\text { I } \\
\text { I } \\
\text { I } \\
\text { I }\end{array}$ & $\begin{array}{l}\text { I } \\
\text { I } \\
\text { I } \\
-\end{array}$ & $\begin{array}{l}\text { I } \\
\text { I } \\
\text { I } \\
-\end{array}$ & $\begin{array}{c}\text { C I } \\
\text { C I } \\
\text { C } \\
\text { C I }\end{array}$ & $\begin{array}{c}\text { C I } \\
\text { C I } \\
\text { C } \\
\text { C I }\end{array}$ & $\begin{array}{c}\text { C I } \\
\text { C I } \\
\text { C I } \\
-\end{array}$ & $\begin{array}{l}\mathrm{C} I \\
\mathrm{C} \\
\mathrm{C} \\
\mathrm{C}\end{array}$ & $\begin{array}{c}C I \\
C \\
C \\
-\end{array}$ & $\begin{array}{l}\text { C I } \\
\text { C } \\
\text { C } \\
-\end{array}$ & $\begin{array}{l}\mathrm{C} \\
\mathrm{C} \\
\mathrm{C} \\
\mathrm{C}\end{array}$ & $\begin{array}{l}\mathrm{C} \\
\mathrm{C} \\
\mathrm{C} \\
\mathrm{C}\end{array}$ & $\begin{array}{l}c \\
C \\
C \\
c\end{array}$ \\
\hline 骕 & $\Rightarrow$ & & & & & & & & & & & & 不良 \\
\hline
\end{tabular}

るが，吸収エネルギーは比例して増加せず，脆性的にな る傾向があるといえる。このような脆性化の理由として は；ペーストマトリックスの強度が大きくなるほど，ひ びわれの進展は骨材とペースト界面間の伝播から骨材を 貫通する破壊モードに移行し，骨材のブリッジング効果 が減少することが挙げられる5!。このことは，破断面の 観察結果からも推察でき, C 50, C 65 等の高水セメント

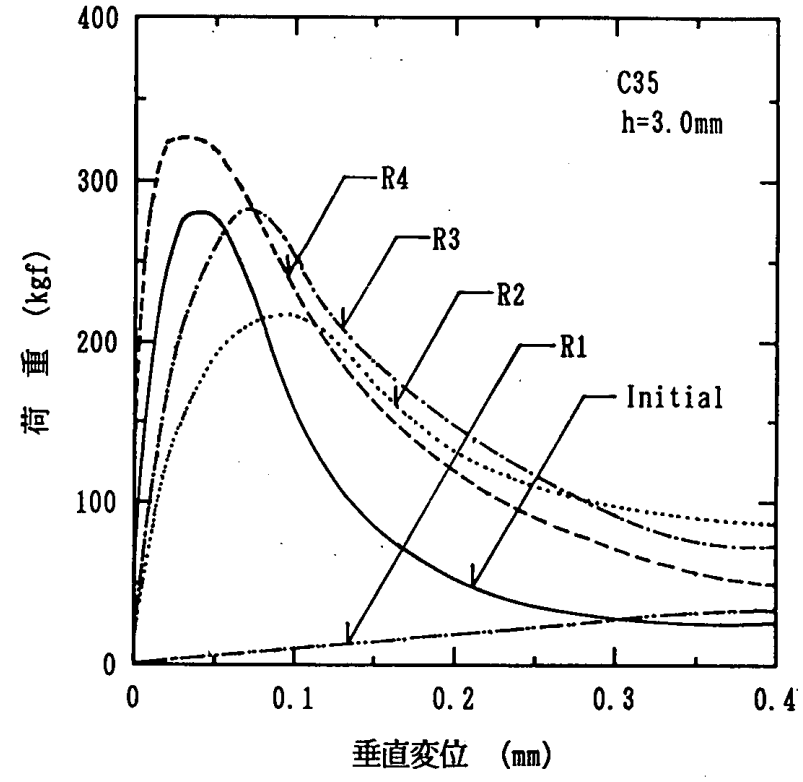

図一6 曲げ試験結果（補修後コンクリート）

比試験体の破断面では骨材が破断せず凹凸状となってい るのに対し，C25 等の低水セメント比試験体の破断面 では骨材が破断し平坦になる傾问があった。

\section{2 補修後試験体の実験結果}

表一6に補修後の曲げ試験で得られた曲げ強度平均值 および変動係数を，表一7に破壊エネルギーの平均值お よび変動係数をまとめて示した。

表一8に補修試験体破壊後の破壊状況をまとめて示し た。破壊の状海により，C：コンクリート破断（コンク リート母材が破断する), I：界面破断(樹脂とコンクリ一 ト面が剝がれて破断する), CI：Cと I の複合に分類し た。なお，いすれれの条件でも樹脂自体の破断は観察され なかった。全体的に樹脂の引張弾性係数が大きくなるほ ど破壊モードは界面破壊からコンクリート破壊に移行す る傾向にある。なお，樹脂 RI はすべての条件で樹脂の 一部のみが界面破断となり試験体は完全破断には至って いない。これは樹脂 RI の伸び能力に起因するものであ る。したがって, 垂直変位は明確な最大值を示さないが, $G_{F}$ を求める場合には荷重がほぼ 0 となる重直変位 $4 \mathrm{~mm}$ を最大值とした。

図一6に補修後の曲げ試験で得られた荷重-変位曲線 の測定例を示す。水セメント比 $35 \%$ ，ひびわれ幅 3.0 $\mathrm{mm}$ の場合について示した。エポキシ樹脂の引張弾性係 数が小さくなるほよ゙荷重-変位曲線は偏平な曲線になり, 荷重に対する変形量が大きくなる。ただし，最大荷重な らびに初期剛性は低下する。したがって, 補修後の曲げ 試験での荷重一変位特性は, 使用したエポキシ樹脂の性 質を反映しており, 高引張弾性係数の樹脂を用いるほど 強度ならびに剛性は大きくなり, 低引張弾性係数の樹脂 を用いるほど強度は低下するが変形能は大きくなる傾向 がある。引張弾性係数の最も大きいエポキシ樹脂 R 4 

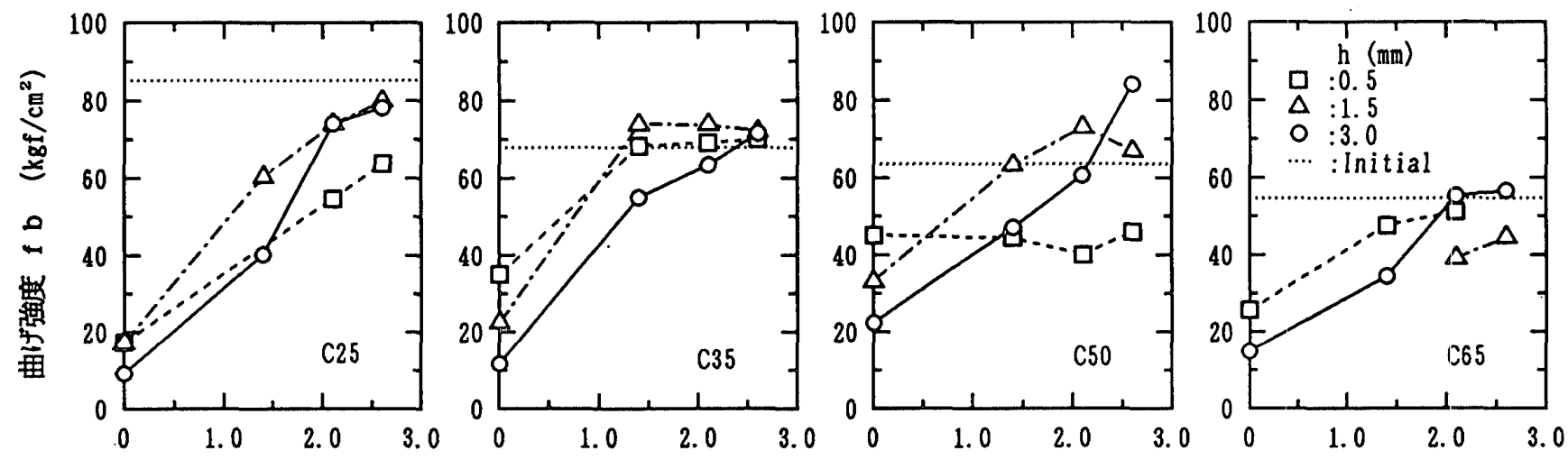

楜脂の引張弾性俰数 E e $\left(* 10^{4} \mathrm{kgf} / \mathrm{cm}^{2}\right)$

図一7 補修試験体の曲げ強度と樹脂の弓張弾性係数との関係
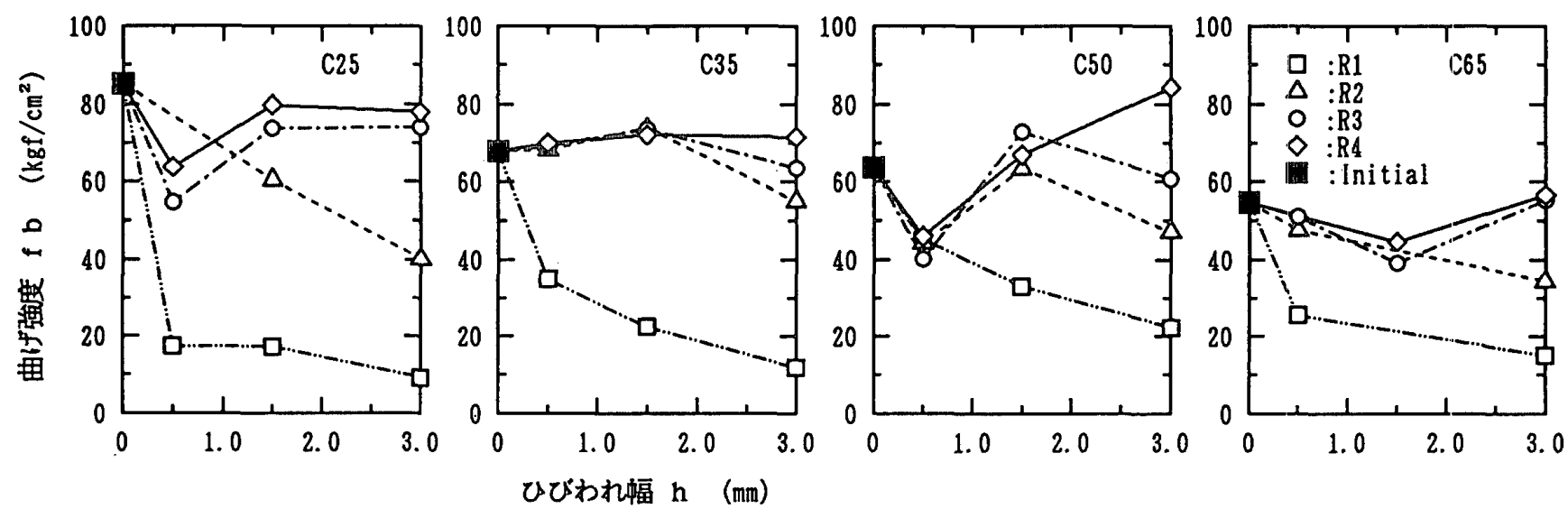

図一8 補修試験体の曲げ強度とひびわれ幅との関係

で補修した結果をみると補修前よりも最大荷重は大きく なっており耐力は向上している。また, 荷重-変位曲線 で囲まれた面積も増加しており, 吸収エネルギーも増大 している。したがって, 適度な引張弾性係数のエポキシ 樹脂を使用することにより, 補修後の風性ならびに勒性 の向上が可能といえる。

\section{3 曲げ強度に関する考察}

図一7に, 補修試験体の曲げ強度と樹脂の引張弾性係 数との関係を試験体の水セメント比別に示す。各水セメ ント比の条件においてエポキシ樹脂の引張弹性係数が大 きくなるほど曲げ強度は增大する。引張弾性係数の最も 大きい樹脂 R 4 では, 補修前の試験体とほぼ同程度の 曲げ強度の回復が得られる。また, 高引張弹性係数の樹 脂では水セメント比が大きくなるほど補修後の曲げ強度 は低下する傾向があるが，低引張弾性係数の樹脂 R 1 では, 試験体の水セメント比にかかわらず曲げ強度はほ ぼ同じ值を示す。すなわち，樹脂の引張弾性係数が大き くなるほよ゙, 曲げ強度はコンクリートの強度に依存し， 樹脂の引張弹性係数が小さい場合には曲げ強度は樹脂の 性質に依存するといえる。このことは，表一8の曲げ試 験での破断状況で, 低引張弾性係数の樹脂の場合は樹脂 とコンクリート界面で破断する場合が多いのに対し，高
引張弾性係数の樹脂の場合はコンクリート母材での破断 が多くなることからも推察できる。この理由には, 接着 剤の引張弾性係数が小さくなるほど接着界面に働く引張 応力が高くなること ${ }^{15)}$, 表一5 の実騟結果に示すように, 今回用いたエポキシ樹脂では引張弾性係数が小さいもの ほどコンクリート破断面との接着力が低下する傾向にあ ることなどが考えられる。

図一8に曲げ強度とひびわれ幅の関係を水セメント比 別に示した。引張弾性係数の低い樹脂では, ひびわれ幅 が大きくなるほど補修後の試験体の曲げ強度は低下する 傾向がある。しかしながら樹脂の引張弾性係数が大きく なるほどこの傾向は不明確になり, 高引張弾性係数の樹 脂では補修後の曲げ強度は補修前とほぼ同じ值か大きな 值を示す。したがって, 樹脂の引張弾性係数が小さくな るほど, 補修後の強度はひびわれ幅の影響を受けやすい と考えられる。ひびわれ幅 $0.5 \mathrm{~mm}$ において，曲げ強度 が低下するものがあるがこれは樹脂の充填不良が原因と 思われる。

\section{4 破壊エネルギーに関する考察}

図一9に破壊エネルギー $G_{F}$ 之樹脂の引張弾性係数之 の関係を水セメント比別に示す。各条件において $G_{F}$ は 補修前よりも同等あるいはそれ以上となっており，樹脂 

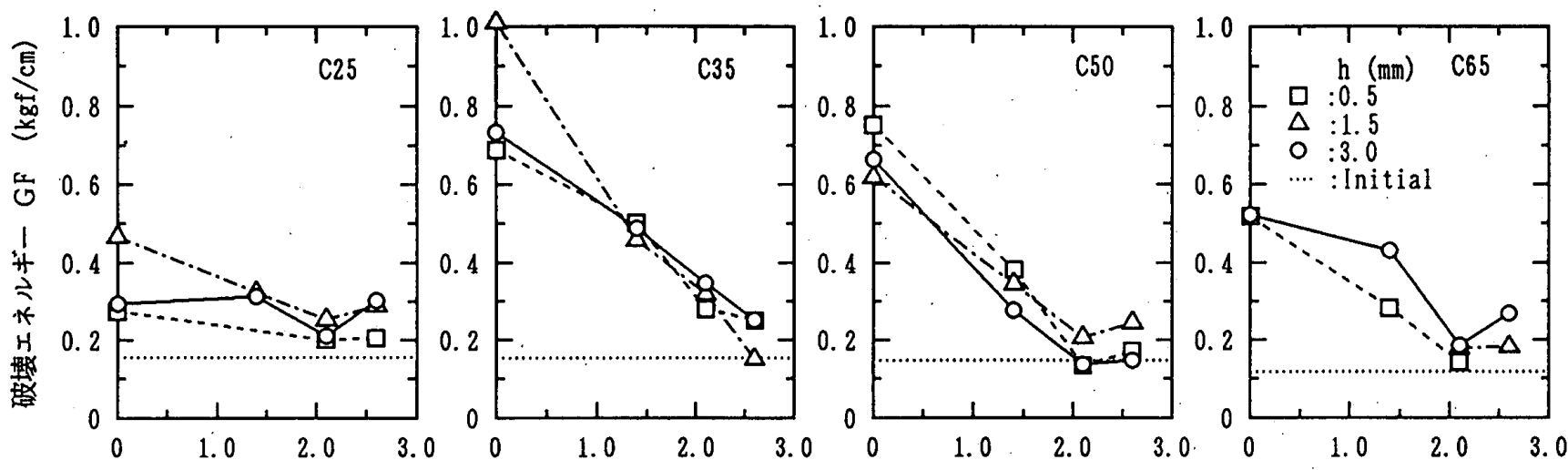

樹脂の引張弾性係数 $\mathrm{E} \mathrm{e} \quad\left(* 10^{4} \mathrm{kgf} / \mathrm{cm}^{2}\right)$

図一9 補修試験体の破壊エネルギーと樹脂の引張弾性係数との関係
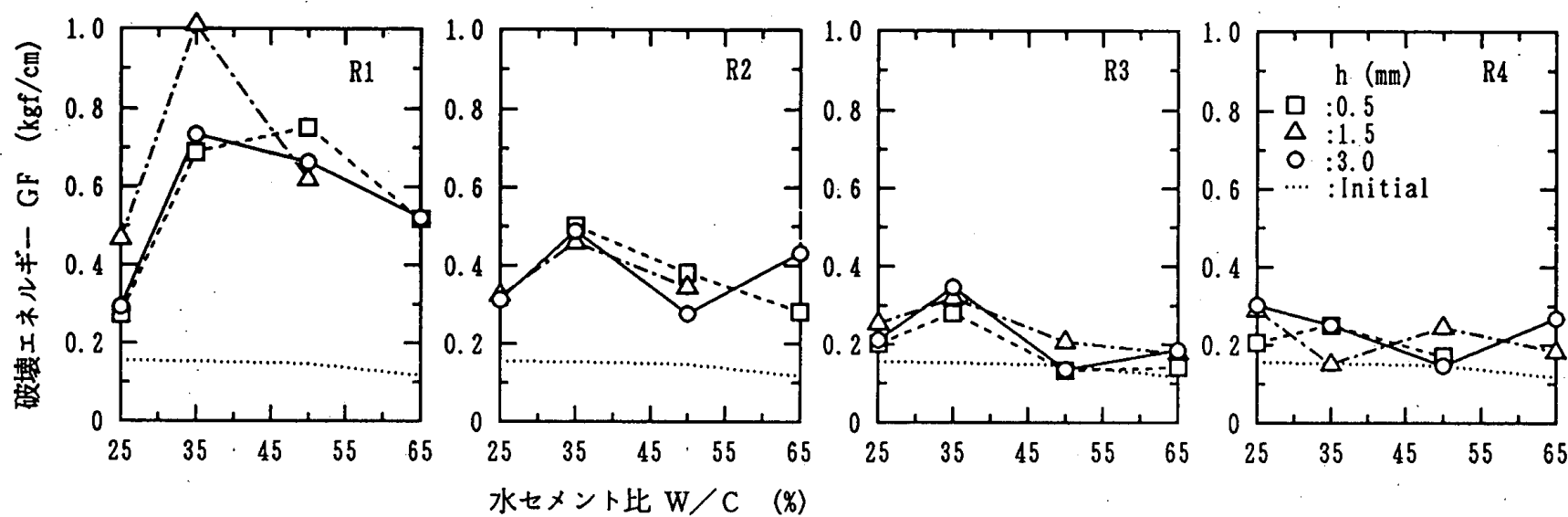

図一10 補修試験体の破壊エネルギーと水セメント比との関係

を用い補修することにより吸収エネルギーの点では増加 傾向が見られる。各水セメント比の条件において, 樹脂 の引張弾性係数が小さくなるほよ゙ $G_{F}$ は直線的に増大し 曲げ強度とは逆の傾向を示す。すなわち, 変形能の大き い樹脂ほど補修後のコンクリートの破壊エネルギーは大 きくなる。また，樹脂の引張弾性係数が大きくなるほど 破壊エネルギーは単純に減少せず, 引張弾性係数 $2.0 \times$ $10^{4} \mathrm{kgf} / \mathrm{cm}^{2}$ 付近で最小值となり, それ以上の引張弾性 .係数では同等あるいはやや向上する傾向がある。特に水 セメント比 $50,65 \%$ の条件で顕著である。

ひびわれ幅と破壊エネルギーとの関係は明確ではな く, 各ひびわれ幅の条件ともほぼ同じ破壊エネルギー值 を示す。

図一10に補修後の試験体の破壊エネルギーと水セメ ント比との関係を補修樹脂の引張弾性係数別に示した。 各引張弾性係数の条件において, 破壊エネルギ一は水セ メント比が小さくなるほど大きくなるが，W/C=35\% で最大となり，W/C=25\%では逆に娍少する傾向があ る。この傾向は低引張弾性係数の樹脂ほど顕著である。 すなわち，コンクリート強度が増大すると，樹脂補修に よる勒性は単純に比例せず, あるコンクリート強度で最 大となる。この理由としては，図一 5 に示したように低
水セメント比ではコンクリート母材自体が脆性的になる ことが挙げられるが, 他の要因として接着破壊面の状態 の差異が考えられる。すなわち, 低水セメント比のコン クリートでは組織が緻密になるため, 樹脂が接着する際 のアンカー効果が低下し接着力が十分得られないこと, 補修前の曲げ試験によるコンクリート破断面が骨材の破 断を含めた平滑面であるため, 補修後の曲げ試験におい て骨材の凹凸によるひびわれ進展の抵抗効果が低诚する ことなどが考えられる。

\section{5 回復率に関する考察}

図一11 には曲げ強度の回復度亡樹脂の引張弾性係数 との関係を示した。両者には比例関係が見られるが，ひ びわれ幅 $3.0 \mathrm{~mm}$ では, 各水セメント比の条件とも樹脂 の引張弾性係数が $2.0 \times 10^{4} \mathrm{kgf} / \mathrm{cm}^{2}$ 付近で回復率が 1 となる。ひびわれ幅が小さくなるほど, 回復率と引張弾 性係数との関係はコンクリートの条件によって異なる傾 向にある。特に水セメント比 $25 \%$ の条件では他の条件 よりも回復率が低くなる。したがって，ひびわれ幅が大 きい場合には, 強度の回復性は樹脂の性質に依存するが, ひびわれ幅が小さくなるほど，コンクリートの条件に影 響を受けやすくなるといえる。

図一 12 には, 補修前後での破壊エネルギーの回復率 

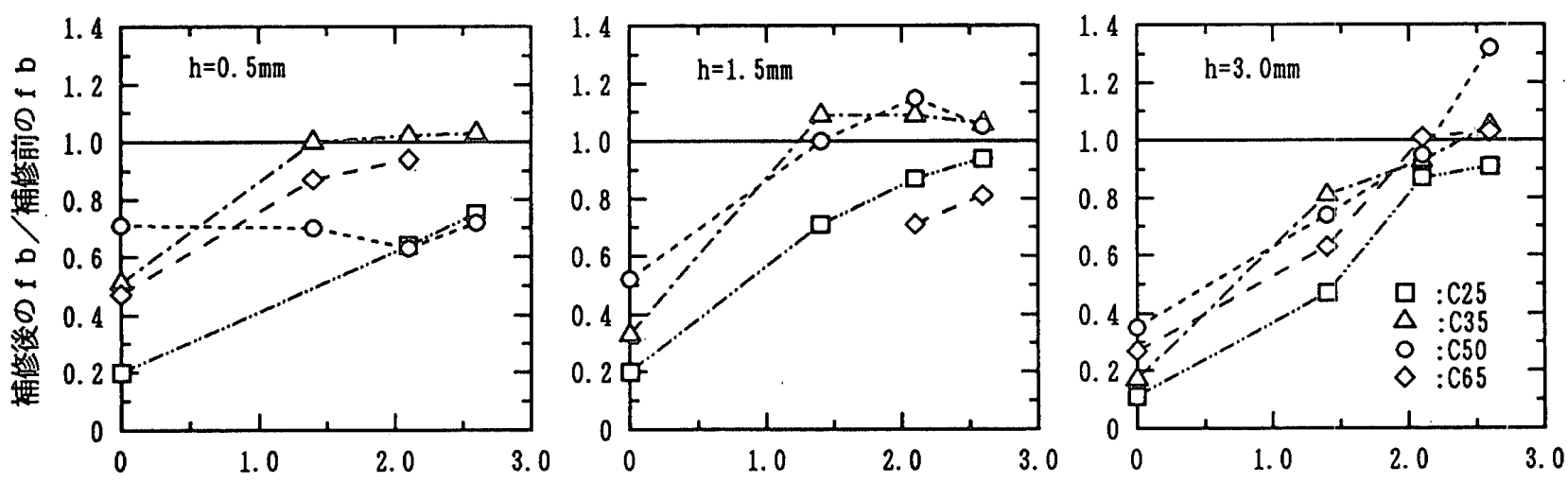

樹脂の引張弾性係数 E e $\quad\left(* 10^{4} \mathrm{kgf} / \mathrm{cm}^{2}\right)$

図一11 曲げ強度の回復率と樹脂の引張弾性係数との関係
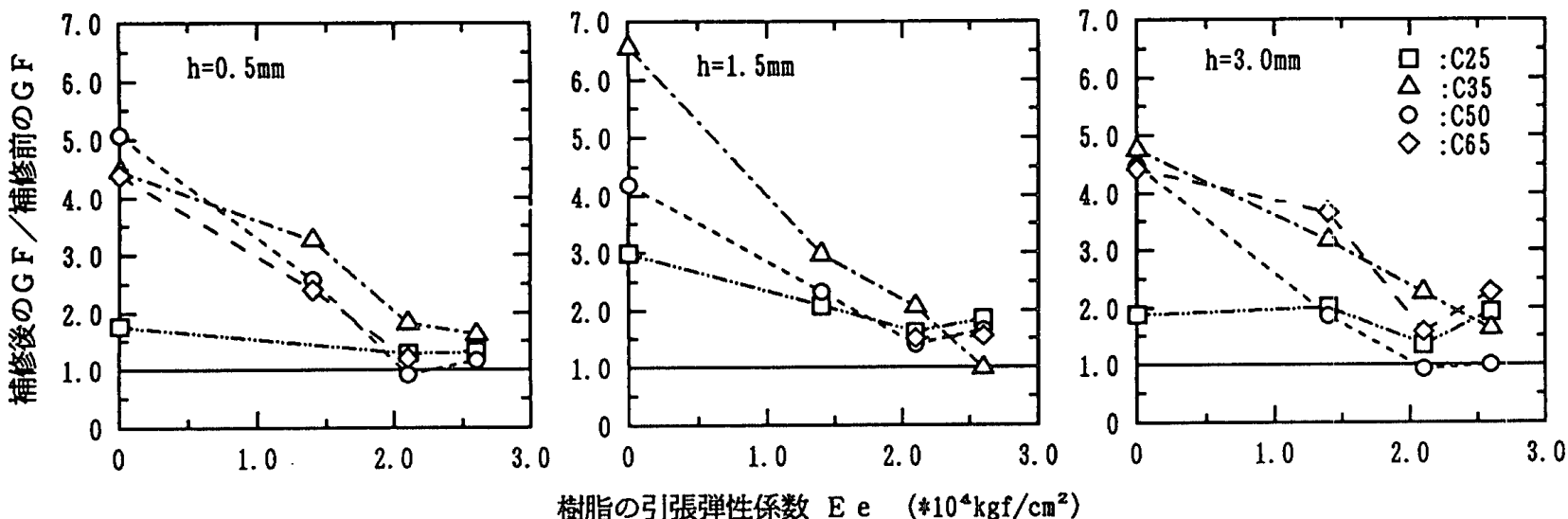

図一12 破壊エネルギーの回復率と樹脂の引張弾性係数との関係

と樹脂の引張弾性係数との関係を示した。各ひびわれ幅 の条件とも, 樹脂の引張弾性係数が増加するほど回復率 は減少し, 樹脂の引張弾性係数 $2.0 \times 10^{4} \mathrm{kgf} / \mathrm{cm}^{2}$ 前後 で回復率は 1 を示す。また, それ以上の引張弾性係数で は回復率はやや上昇する傾向にある。水セメント比 25 \%では回復率の変化は少ない。

\section{5. 結 論}

エポキシ樹脂によるひびわれ補修前後の試験体の曲げ 強度ならびに破壊エネルギーに及ぼす樹脂の引張弾性係 数, コンクリート強度, ひびわれ幅等の影響について検 討した結果，本実験の範囲で以下が明らかになった。

（1）今回使用したエポキシ樹脂では引張弾性係数が大 きくなるほど補修後の試験体の曲げ強度は大きくなる傾 向がある。

（2）補修後の試験体の曲げ強度は，ひびわれ幅が大き くなるほざ小さくなる傾向があり，それは樹脂の引張弾 性係数が低くなるほど顕著に見られる。

（３）補修後の試験体の破壊エネルギーは, 補修前より も同等あるいはそれ以上となり，樹脂の引張弾性係数が 小さくなるほど直線的に増大する。また，引張弾性係数 が $2.0 \times 10^{4} \mathrm{kgf} / \mathrm{cm}^{2}$ 前後で最小值となる傾向があった。
（4）コンクリート強度が増大すると樹脂補修による破 壊エネルギーは単純に比例せず， $W / C=35 \%$ 前後で ピークとなりそれ以上は減少傾向を示す。これは低引張 弾性係数の樹脂ほど顕著である。

今後の課題として, 広範囲の材質の補修材料の評価, 部材レベルでの評価への対応, 混合破壊モードでの評価 等が挙げられる。

\section{謝 辞}

実験試料にご協力頂きました, ダイヤリフォーム (株)，山宗化学 (株)ならびにサンコレジン (株) に感謝 いたします。また実験にご協力頂きましたスミセコンク リートエンジニアリング (株) ならびに金子和人氏（宇 大技官), 高瀬憲克氏（元宇都宮大学院生, 現住收建設） に感謝いたします。

\section{参考文献}

1）日本コンクリート工学協会：コンクリートのひびわれ調 查, 補修·補強指針, pp. 89 103

2) Collins, F. and Roper, H. : Laboratory Investigation of Shear Repair of Reinforced Concrete Beames Lcaded in Flexure, ACI Materials Journal, Vol.97, No.2, pp. 149 -159, March-April, 1990

3) Basunbul, I. A., Gubati, A.A., Al-Sulaimani, G. J. 
and Baluch, M.H. : Repaired Reinforced Concrete Beames, ACI Materials Journal, Vol. 87, No. 4, pp. 348 $\sim 354$, July-August, 1990

4) Shah, S. P. : Fracture Toughness for High-Strength Concrete, ACI Materials Journal, Vol.87, No.4, pp. 260 265, July-August, 1990

5）野村希晶，三橋博三，鈴木，篤，和泉正哲：非線形破壊 力学手法に基づく高強度コンクリートの脆性化機構の考 察, 日本建築学会構造系論文報告集, 第 416 号, pp. 9 $16,1990.10$

6）上村克郎，小西敏正，橘高義典：コンクリートのひびわ れ補修における樹脂の充媜程度の数式化，セメント技術 年報, No. 42 , pp. $491 \sim 494,1988.12$

7) 今泉勝吉, 青山 幹, 林 好正, 国原安彦: 接着された 部材の力学的性状に関する研究（その1 接着面積・接 着層厚の接着強度・変形能に及ぼす影響の検討), 日本建 築学会大会学術講演梗概集 (関東), pp. $555 \sim 556$, 1988. 10

8）国原安彦，今泉勝吉，青山幹，林 好正：接着された 部材の力学的性状に関する研究 (その 2 割裂接着強度 試験による接着強度と接着層の変形能の検討), 日本建築 学会大会学術講演梗概集 (九州), pp. 831 832, 1989. 10

9）国原安彦，今泉勝吉，青山幹，林好正：接着された 部材の力学的性状に関する研究（その 3 ひびわれ性状 が割裂接着強度に及ぼす影響の検討)，日本建築学会大会
学術講演梗概集 (中国), pp. 257 258, 1990. 10

10) Kleinschrodt, H.D. : Evaluation of Force-locking Epoxy-resin Injection in Concrete Cracks by Meanes of Fracture Mechanics Parameters, Fracture of Concrete and Rock : Recent Developments, Elsevier Applied Science, pp. $537 \sim 548,1989$

11) JIS A 6024：建築補修用注入エポキシ樹脂

12）長滝重義, 岡本亭久, 兽我寿考：断面修復した鉄筋コン クリートはりの力学挙動と合理的補修設計法の提案, コ ンクリート工学年次論文報告集, 12-1, pp. 1281 1286, 1990.7

13）柿崎正義, 枝広英俊：コンクリート構造物の品質向上に 向けて, その 2 ・補修方法はどれがよいか, セメント・ コンクリートNo.512, pp.52〜66, Oct. 1989

14) 50 -FMC Committee : Determination of the Fracture Energy of Mortar and Concrete by Means of Three-point Bend Tests on Notched Beames, Materials and Structures, RILEM, Vol. 18, No. 106, pp. 285 290, 1985.7, 8

15) Keer, J.G. and Emberson, N.K. : A Theoretical and Experimental Study on Concrete Members Repaired by Resin In jection, Proceedings of an International Symposium Organized by RILEM Technical Committee 52, sept. pp. 16 19, 1986

(1991 年 7 月 10 日原稿受理, 1991 年 11 月 28 日採用決定) 